\title{
The Contributions of Temperament Characteristics to Attachment in 6-Year-Old Children
}

\author{
İsa Kaya ${ }^{1}$, Serdal Seven ${ }^{1} \&$ Gökçen İlhan Ildız ${ }^{2}$ \\ ${ }^{1}$ Early Childhood Education Department, Fatih Sultan Mehmet Foundation University, İstanbul, Turkey \\ ${ }^{2}$ Tekirdağ Child Development Program, Tekirdağ Namık Kemal University, Tekirdağ, Turkey \\ Correspondence: İsa Kaya, Early Childhood Education Department, Fatih Sultan Mehmet Foundation University, \\ İstanbul, Turkey.
}

Received: March 2, 2020

Accepted: April 26, 2020

Online Published: June 25, 2020

doi:10.5539/ies.v13n7p156

URL: https://doi.org/10.5539/ies.v13n7p156

\begin{abstract}
The aim of the current study is to investigate whether 6-year-old children's temperament predict their level of attachment. The study has a descriptive design. During the Spring term of the academic year 2017-2018, 59 children (60-72-month old) and their mothers in City of Tekirdağ (Süleymanpaşa District) volunteered to participate in the study. Demographics Form, Incomplete Stories with Doll Family and Short Temperament Scale for Children were used for the data collection. Descriptive statistics were performed to summarize the ISDF and STSC scores in the first step of the data analysis. A multiple linear regression was carried out and attachment scores and temperament sub-dimension scores were assigned as the dependent and independent variables, respectively. Multiple linear regression analyses revealed that the independent variables in the model predicted $16 \%$ of the dependent variable $\left(\mathrm{R}^{2}=.157\right)$, which meant that the children's temperament predicted $16 \%$ of their attachment levels. Reactivity, sociability, rhythmicity and the linear combination of children's reactivity, persistence, sociability and rhythmicity did not predict children's attachment, but persistence did.
\end{abstract}

Keywords: 6-year-old, early childhood, attachment, temperament

\section{Introduction}

Attachment is the formation of emotional bonds between infants and adults. Bowlby (1973), the father of attachment theory, defines attachment as the strong, meaningful, intimate and durable emotional bonds that human beings form with significant others while Ainsworth, Blehar, Waters, and Wall (2015) specify that it is a constant and emotional tie between an infant and his/her caregiver. Bowlby (2008) states that an infant is supposed to see his/her caregiver as a secure base in stressful situations and feel anxious when the caregiver is away.

Ainsworth (1978), who systematized the attachment theory, identified four attachment styles, which are secure, insecure, avoidant and resistant attachment with the "Strange Situation Experiment" that she developed. Following Ainsworth, Main and Solomon (1986) included another attachment style called disoriented attachment in the classification of the attachment styles based on the findings of their research.

The attachment of an infant where the infant tries to draw the attention of the caregiver while he or she warms to the caregiver at the same time (Bowlby, 1969) founds the basis of healthy social and emotional development, linguistic and communicative competence, positive sense of self, positive and negative opinions of others and a secure base for exploration behaviors regarding cognitive development (Bowlby, 1982; 1969). A secure attachment contributes to the development in infancy and early childhood while an insecure attachment is very likely to result in negative consequences for children's development (İlhan-Ildız \& Ahmetoğlu, 2016).

There are many child-based and mother-based factors affecting mother-infant attachment. A mother's sensitivity to her child's reactions plays a critical role in attachment. It is important for a mother to be sensitive to her baby's basic and emotional needs for the formation of healthy bonds (Berk, 2013). Another factor affecting attachment is the internal working models of parents, specifically the previous attachment experiences of parents because parents who have formed secure attachments are more likely to form similar attachments with their infants (Bowlby, 1973). One of the child-based factors is the physical appearance of infants, which seems to have an influence on mother's attachment to their babies, as it is associated with the amount of caregiving behavior. For instance, unattractive physical appearance may result in less or more caregiving behavior. Temperament as a 
child-based factor has also been long debated with significant splits of opinion in literature (Illhan-Ildız, 2016).

Rothbart and Bates (1998) define temperament as "the individual differences in emotional, motor and attentional reactivity and self-regulation" that children consistently display in all kinds of settings and situations. Thomas and Chess (1977) have identified nine traits of temperament, which are activity level, biological regularity, adaptability, approach/withdrawal, sensitivity threshold, intensity of emotional response, distractibility, quality of mood and persistence/attention span, and three temperament types, which are easy/flexible, difficult/feisty and the slow-to-warm-up/fearful child. The flexible child having positive feelings is easy for caregivers which is the opposite of the feisty child may be unpleasant, disagreeable and hard to get used to anything new while the slow-to-warm-up children tend to avoid the new and unfamiliar (Burger, 2006). Although these traits can be shaped by environmental factors, they are biologically based (Buss \& Plomin, 2014). Thomas and Chess (1977), who have worked on temperament longitudinally, found that temperament could increase a child's chances of having psychological problems or protect a child from the effects of stressful life. Although temperament develops in the early years and it is biologically based and relatively permanent, it is still a series of traits with multiple dimensions that is vulnerable to the environmental changes (Wachs \& Bates 2010).

\subsection{Current Study}

There are two camps of opinion as to the effects of temperament on the development of attachment. One school of thought is that temperament has an impact on attachment. Goldsmith and Alansky (1987) claimed that temperament affects attachment by directing mother-infant interactions. The other one holds that as temperament is biologically based, it cannot be the single factor affecting attachment that is developed in the postnatal period. This view proposes that if temperament was one of the factors shaping attachment, then it would be impossible for an infant to securely attach to one of the parents while being insecurely attached the other one at the same time (Bee \& Boyd, 2009). The research on temperament has focused on its association with adaptation to school (Akbaş, 2016; Liew, Castillo, Chang, \& Chang, 2011), play behaviors (Özdemir \& Budak, 2019; Struby, 2012), social skills (Zembat, Yılmaz, \& Küsmüş, 2018), academic performance (Stright, Gallagher, \& Kelley, 2008), parental attitudes (Yaman, 2018). There are also studies investigating the effects of temperament, attachment and maternal sensitivity to adaptation in mid-childhood (Stams, Juffer, \& Van IJzendoorn, 2002), temperament and attachment security (Belsky \& Rovine, 1987; Vaughn, Lefever, Seifer, \& Barglow, 1989), temperament and attachment security and the relationship between attachment security, temperament and peer acceptance (Szewczyk-Sokolowski, Bost, \& Wainwright, 2005). The current study will contribute to the existing research by exploring the effects of temperament on children's attachment. The aim of the current study is to investigate the predictive effects of 6-year-old children's temperament traits on their attachment. Therefore, the following research questions are addressed in this study:

(1) Are the temperament traits of 6-year-old children (approach, persistence, rhythmicity and reactivity) related to their attachment?

(2) Do the temperament traits of 6-year-old children (approach, persistence, rhythmicity and reactivity) predict attachment?

\section{Method}

\subsection{Research Design}

The current study has a qualitative design with a relational approach in order to better understand the phenomena by investigating the links between variables. Correlational and causal-comparative designs are examples of relational methods (Büyüköztürk, Çakmak, Akgün, Karadeniz, \& Demirel, 2012).

\subsection{Participants}

Participants were selected based on criterion sampling which is a sampling method to select the subjects satisfying some pre-determined criterion (Büyüköztürk, Çakmak, Akgün, Karadeniz, \& Demirel, 2012). The criteria to participate in the study were being a mother having a six years old child without any disabilities. During the Spring term in 2018, typically developing 59 children (60-72-month old) and their mothers in Süleymanpaşa District in City of Tekirdağ volunteered to participate in the study. There were 32 girls $(54.2 \%)$ and 27 boys $(45.8 \%) .34$ of the children were $60-66$-months-old while 25 of them were $67-72$-months-old. 7 of the mothers $(11.8 \%)$ were graduates of primary school while 31 of the mothers (52.5\%) graduated from high school. Only $9(15.2 \%)$ and 12 of the mothers $(20.33 \%)$ had an associate's and bachelor's degree, respectively. 29 of the mothers aged 20-30 (45.15\%), 21 aged $31-40(35.5 \%)$ and 9 of them were 41 or older. The mean age of the participating mothers was 29.8 . 


\subsection{Data Collection Tools}

Demographics Form, Incomplete Stories with a Doll Family (Cassidy, 1988) and Short Temperament Scale for Children (Prior, Sanson, \& Oberkleid, 1989) were used for the data collection.

\subsubsection{Demographic Form}

Developed by the researchers, it aims to collect demographic data from the participating children and parents.

\subsubsection{Short Temperament Scale for Children}

Developed by Prior, Sanson, and Oberklaid (1989) and adapted to Turkish by Yagmurlu and Sanson (2009), Short Temperament Scale for Children is rated on a 6-point Likert scale. It has 30 items with four dimensions, which are Reactivity, Persistence, Approach and Rhythmicity. Reactivity refers to a child's tendency to get upset or annoyed with a task while persistence is a child's pleasure in completing a task before going to the next. Approach is the shyness of a child when introduced to new people and environments while rhythmicity measures the rhythm of a child's functioning (sleep, meals, toilet)

\subsubsection{Incomplete Stories with a Doll Family (ISDF)}

ISDF is a projective, story-based measure, which was developed by Cassidy (1988) to identify attachment styles of children and adapted to Turkish by Seven (2006). Children are asked to complete six 3-minute stories which are told with puppets. The stories which aim to reflect cognitive self-representation of a child related to attachment reveal whether the child is securely attached to his/her parent. In other words, they show whether the child is respected, feels confident and safe in child-parent dyad where conflicts and stressful situations are resolved within the relationship (Cassidy, 1988; Seven, 2006).

\subsection{Data Analysis}

The data was analyzed in two steps. In the first step, descriptive statistics were performed to describe children's perceptions of their attachment relationships with their parents. In the second step, the descriptive statistics were used for the Multiple Linear Regression Analysis. Mahalanobis distance was used to exclude three values below 0.001 from the data cluster and 59 participants were included in the sample accordingly. The scatter diagram with standardized residuals and standardized predicted values indicate a linear relationship where the scores were plotted around the center line and that histogram and normal distribution curves had a relatively normal distribution. The variance inflation factor (VIF) was used to investigate multicollinearity. The VIF values for Reactivity, Persistence, Approach and Rhythmicity subdimensions of the Short Temperament Scale for Children were 1.072, 1.049, 1.155 and 1.056, respectively indicating collinearity between the variables. Multiple linear regression was carried out with the data obtained where ISDF scores and STSC scores were designated as the dependent and independent variables, respectively.

\section{Results}

The findings of the multiple regression analysis are presented in Table 1 and 2.

Table 1. Pearson correlation analysis findings for independent variables

\begin{tabular}{cccccc}
\hline Pearson Correlation Attachment Reactivity Persistence Approach Rhythmicity \\
\hline Attachment & - & & & \\
Reactivity & .174 & - & & \\
Persistence & $.283^{*}$ & -.013 & - & \\
Approach & .089 & .231 & .188 & - \\
Rhythmicity & -.231 & -.052 & -.046 & .189 & - \\
\hline
\end{tabular}

Correlation coefficients that range between 0 and 0.30 indicate that there are no associations between the variables. A value ranging from 0.31 to 0.49 means a weak association. If it is between 0.50 and 0.69 or greater than 0,70 , it indicates a moderate or strong relationship, respectively (Sönmez \& Alacapınar, 2011). Pearson Correlation in Table 1 shows that there is no correlation between the independent variables. It also indicates no multiple linear relationships between the variables, which mean that the data is suitable for multiple linear regression analysis. A strong correlation between independent variables suggests that they have similar predictive power for the dependent variable. 
Table 2. Multiple linear regression analysis results for temperament predicting attachment

\begin{tabular}{ccccc}
\hline Mode & $\mathrm{R}$ & $\mathrm{R}^{2}$ & $\begin{array}{c}\mathrm{R}^{2}\left(\Delta \mathrm{R}^{2}\right) \\
\text { Change }\end{array}$ & $\mathrm{P}$ \\
\hline 1. & .397 & .157 & .95 & 0.52 \\
\hline
\end{tabular}

Table 2 shows that the independent variables in the model predicted $16 \%$ of the dependent variable $\left(\mathrm{R}^{2}=157\right)$. Therefore, children's temperament traits may predict $16 \%$ of children's attachment level. However, the linear combination of Reactivity, Persistence, Approach and Rhythmicity in Table 2 did not predict attachment level $(\mathrm{p}>.05)$.

Table 3. B and beta correlation coefficients and significance levels

\begin{tabular}{ccccccc}
\hline Predictors & $\mathrm{F}$ & $\mathrm{B}$ & $\mathrm{SE}$ & $\beta$ & $\mathrm{t}$ & $\mathrm{p}$ \\
\hline Constant & 2.519 & 15.811 & 5.151 & & 3.069 & .003 \\
Reactivity & & .100 & .083 & .156 & 1.203 & .234 \\
Persistence & & .175 & .084 & .267 & 2.087 & $.042^{*}$ \\
Approach & & .042 & .127 & .044 & .329 & .744 \\
Rhythmicity & & -.224 & .131 & -.219 & -1.706 & .094 \\
\hline
\end{tabular}

$* \mathrm{p}<.05$.

The formula obtained from the regression analysis with multiple variables is as follows: Attachment $=15.811+0.1 *$ Reactivity $+0.17 *$ Persistence $+0.042 *$ Approach $0.224 *$ Rhythmicity. The results of the regression analysis carried out to investigate whether Reactivity, Persistence, Approach and Rhythmicity subdimensions predict Attachment are presented in Table 6. It shows that only Persistence significantly predicted children's attachment level ( $\mathrm{t}(2.087), \mathrm{p}<.05)$, while Reactivity ( $\mathrm{t}(1.203), \mathrm{p}>.05)$, Approach ( $\mathrm{t}(.329), \mathrm{p}>.05)$, and Rhythmicity (t(-1.706), $\mathrm{p}>.05)$ did not.

Multiple linear regression analyses revealed that the independent variables in the model predicted $16 \%$ of the dependent variable $\left(\mathrm{R}^{2}=157\right)$, which meant that the children's temperament predicted $16 \%$ of their attachment levels. The linear combination of children's reactivity, persistence, sociability and rhythmicity, reactivity, sociability, and rhythmicity did not predict children's attachment, but persistence did.

\section{Discussion}

The results of the multiple linear regression analyses indicated that the independent variables in the model predicted $16 \%$ of the dependent variable $\left(\mathrm{R}^{2}=.157\right)$. Therefore, children's temperament traits may predict $16 \%$ of children's attachment level. However, the linear combination of Reactivity, Persistence, Approach and Rhythmicity did not predict attachment level $(\mathrm{p}>.05)$ in the proposed model. Only Persistence significantly predicted the attachment level while Reactivity, Approach and Rhythmicity subdimensions of STSC did not.

The finding of the current study suggesting that temperament traits are not likely to predict children's attachment and that there is a weak correlation between temperament and attachment is consistent with the findings of the previous research. Vaughn et al. (1989), who investigated the attachment behavior in infancy, attachment security and temperament, found that temperament did not predict attachment security. In their experimental research with the Strange Situation, Belsky and Rovine (1987) concluded that temperament may not be an important factor in labelling attachment as secure or insecure. Similarly, Groh et al. (2017) did a meta-analysis on the relationship between temperament and attachment in the early years and found only a weak association between temperament and attachment security.

On the other hand, there are also research findings indicating a strong association between children's attachment styles and temperament traits. Murphy et al. (2019) worked with children with a mean age of 56.92 months and mothers and found a negative correlation between secure attachment and jealousy. Similarly, Kökçü and Kesebir (2010) reported strong correlations between attachment styles and temperament.

There are other studies where persistence as a temperament trait predicted some other variables (Erdoğan, Yoleri, \& Tetik, 2017; Önder, Dağal, \& Bayındır, 2018). Önder et al. (2018) found that persistence together with reactivity moderately predicted authoritative and permissive parenting styles and ego integrity while Erdoğan et al. (2017) stated that persistence and rhythmicity predicted democratic and authoritative parenting styles but not permissive or overprotective parenting styles. Zembat et al. (2018) examined the relationship between reactivity/approach, 
rhythmicity/persistence subdimensions and social skills and found a significant relationship between social skills and persistence only.

The studies in literature focusing on the relationship between attachment and temperament in the early years have been carried out in various cultures. Most of them have reached the conclusion that temperament has an impact on children's social and emotional development whereas it is often not the single and most important factor explaining attachment. Attachment is the very emotional bond between the mother and infant in the early years and depends on mother-infant interactions whereas temperament is a child-related factor and cannot explain attachment alone even if it has some effect on attachment. Taking all these into account, the results of the current study is consistent with earlier research.

\section{Recommendations}

The current study is limited to the spring term in 2018, 59 children (60-72-month old) from two preschools and their parents in City of Tekirdağ. Future research may be carried with greater sample sizes. This study focused only on the relationship between children's temperament traits and their attachment levels. Instead of approaching the topic by focusing on all the dimensions of temperament with positive and negative behavioral patterns, future research may have a more specific design addressing each temperament trait separately with different tools and children of different ages, which will provide deeper insights into theory. Longitudinal studies may be of great to have a better understanding the relationship between temperament and attachment as well. Lastly, the overall assessment of other variables that can be related to attachment and temperament will yield more reliable results for the predictive power of temperament.

\section{References}

Ainsworth, M. D. S., Blehar, M. C., Waters, E., \& Wall, S. N. (2015). Patterns of Attachment: A Psychological Study of the Strange Situation. Psychology Press Classic Editions. https://doi.org/10.4324/9780203758045

Akbaş, B. (2016). Okul öncesi eğitim kurumuna devam eden 60 ay ve üzeri çocukların sosyal uyum becerileri ile mizaç özellikleri arasındaki ilişkinin incelenmesi (Unpublished master thesis). Aksaray University Institution of Social Sciences

Bee, H. L., \& Boyd, D. R. (2009). Psychology of Child Development. In O. Gündüz (Ed., p. 616). Kaknüs Publications.

Belsky, J., \& Rovine, M. (1987). Temperament and attachment security in the strange situation: An empirical rapprochement. Child development, 787-795. https://doi.org/10.2307/1130215

Berk, L. E. (2013). Infants and Children. In Ç. E. N. I. Erdoğan (Ed.), Prenatal Through Middle Childhood (Vol. 7). Ankara: Nobel Publications.

Bowlby, J. (1969). Attachment. Attachment and loss (Vol. 1). New York: Basic Books.

Bowlby, J. (1973). Separation: Anxiety and Anger. Hogarth.

Bowlby, J. (1982). Attachment and Loss (Vol. 1 Attachment, 2nd ed.). Tavistock Institute of Human Relations, New York: Basic Books.

Bowlby, J. (2008). A secure base: Parent-child attachment and healthy human development. Basic books.

Burger, J. M. (2006). Personality. In İ. D. E. Sarıoğlu (Ed.,Vol. 1., pp. 350-365). İstanbul: Kaknüs Publications.

Buss, A. H., \& Plomin, R. (2014). Temperament (PLE: Emotion): Early developing personality traits. Psychology Press. https://doi.org/10.4324/9781315745701

Büyüköztürk, Ş., Çakmak, E. K., Akgün, Ö. E., Karadeniz, Ş., \& Demirel, F. (2012). Bilimsel araştırma yöntemleri Pegem Atıf İndeksi (Vol. 13, pp. 1-25). Ankara: Pegem Akademi. https://doi.org/10.14527/9789944919289

Cassidy, J. (1988). Child-mother attachment and the self in six-year-olds. Child development, 121-134. https://doi.org/10.2307/1130394

Erdoğan, N. I., Yoleri, S., \& Tetik, G. (2017). Ebeveyn tutumlarının okul öncesi dönemdeki çocukların mizaç özellikleri ile ilişkisinin incelenmesi. Journal of Mehmet Akif Ersoy University Educational Sciences, 42, 226-239. https://doi.org/10.21764/efd.88048

Goldsmith, H., \& Alansky, J. A. (1987). Maternal and infant temperamental predictors of attachment: A meta-analytic review. Journal of consulting and Clinical Psychology, 55(6), 805. 
https://doi.org/10.1037/0022-006x.55.6.805

Groh, A. M., Narayan, A. J., Bakermans-Kranenburg, M. J., Roisman, G. I., Vaughn, B. E., Fearon, R. P., \& van IJzendoorn, M. H. (2017). Attachment and temperament in the early life course: A meta-analytic review. Child development, 88(3), 770-795. https://doi.org/10.1111/cdev.12677

Ildız, G. İ. (2016). Okul öncesi dönem çocuklarının bağlanma durumlarının incelenmesi (Unpublished Master Thesis), Trakya University, Instutition of Social Sciences, Primary Education, Edirne, Türkiye.

İlhan-Ildız, G., \& Ahmetoğlu, E. (2016). An examination of attachment status of preschool children. International Education Studies, 9(12), 232-243. https://doi.org/10.5539/ies.v9n12p232

Kökçü, F., \& Kesebir, S. (2010). İki uçlu olgular ve çocuklarında bağlanma biçiminin mizaç, kişilik ve klinik özellikler ile ilişkisi: kontrollü bir çalışma. Türk Psikiyatri Dergisi, 21(4), 309-318.

Liew, J., Castillo, L. G., Chang, B. W., \& Chang, Y.-P. (2011). Temperament, self-regulation, and school adjustment in Asian American children. Asian American and Pacific island children's mental health, 1, 121-141.

Main, M., \& Solomon, J. (1986). Discovery of a new insecure-disorganized/disoriented during the Ainsworth Strange Situation. Affective development in infancy, 95-124.

Murphy, T. P., McCurdy, K., Jehl, B., Rowan, M., \& Larrimore, K. (2019). Jealousy behaviors in early childhood: Associations with attachment and temperament. International Journal of Behavioral Development, 44(3), 266-272. https://doi.org/10.1177/0165025419877974

Önder, A., Dağal, A. B., \& Bayındır, D. (2018). Okul Öncesi Dönem Çocukların Mizaç Özellikleri ve Annelerinin Ebeveynlik Stillerinin Çocukların Ego Sağlamlık Düzeyleri Üzerindeki Yordayıcı Etkisi. Education and Science, 43(193). https://doi.org/10.17051/ilkonline.2019.506978

Özdemir, A. A., \& Budak, K. S. (2019). Mizaç ve öz-düzenlemenin çocukların oyun davranışını yordamadaki rolü. Journal of Pamukkale University Education Faculty, 45(45), 78-98. https://doi.org/10.9779/puje.2018.223

Prior, M. R., Sanson, A. V., \& Oberklaid, F. (1989). Temperament in childhood. In G. A. Kohnstamm, J. E. Bates, \& M. K. Rothbar (Eds.), The Australian temperament project (pp. 537-554). Chichester, England: Wiley.

Rothbart, M., \& Bates, J. (1998). Temperament. Hoboken: NJ: Wiley.

Seven, S. (2006). Altı yaş çocuklarının sosyal beceri düzeyleri ile bağlanma durumları arasındaki ilişkilerin incelenmesi (Unpublished PhD thesis), Gazi University Institute of Educational Sciences, Ankara.

Stams, G.-J. J., Juffer, F., \& Van IJzendoorn, M. H. (2002). Maternal sensitivity, infant attachment, and temperament in early childhood predict adjustment in middle childhood: The case of adopted children and their biologically unrelated parents. Developmental Psychology, $38(5), \quad 806$. https://doi.org/10.1037/0012-1649.38.5.806

Stright, A. D., Gallagher, K. C., \& Kelley, K. (2008). Infant temperament moderates relations between maternal parenting in early childhood and children's adjustment in first grade. Child development, 79(1), 186-200. https://doi.org/10.1111/j.1467-8624.2007.01119.x

Struby, J. D. (2012). Preschoolers, parentes and peers: Child temperament and parenting styles as predictors of peer play (Master of arts), Appalachian State University.

Szewczyk-Sokolowski, M., Bost, K. K., \& Wainwright, A. B. (2005). Attachment, temperament, and preschool $\begin{array}{lllll}\text { children's peer acceptance. Social Development, } & \text { 14(3), }\end{array}$ https://doi.org/10.1111/j.1467-9507.2005.00307

Vaughn, B. E., Lefever, G. B., Seifer, R., \& Barglow, P. (1989). Attachment behavior, attachment security, and temperament during infancy. Child development, 728-737. https://doi.org/10.2307/1130738

Wachs, T. D., \& Bates , J. E. (2010). Temperament. In L. Murray, S. Halligan, P. Cooper, J. Bremner, \& T. Wachs (Eds.), The Wiley-Blackwell Handbook of Infant Development. Wiley-Blackwell https://doi.org/10.1002/9781444327564.ch20

Yagmurlu, B., \& Sanson, A. (2009). Parenting and temperament as predictors of prosocial behaviour in Australian and Turkish Australian children. Australian Journal of Psychology, 61(2), 77-88. https://doi.org/10.1080/00049530802001338

Yaman, B. (2018). The role of parental attitudes on children's temperament characteristics and emotion 
regulation skills (Unpublished master thesis), Işık University, Institute of Social Sciences.

Zembat, R., Yılmaz, H., \& Küsmüş, G. İ. (2018). Okul öncesi döenm çocuklarının mizaç özellikleri ile sosyal becerileri arasındaki ilişkinin incelenmesi In S. Dinçer (Ed.), Education in a Changing World (Vol. 1, pp. 43-56). Ankara: Pegem. https://doi.org/10.14527/9786052412480.03

\section{Copyrights}

Copyright for this article is retained by the author(s), with first publication rights granted to the journal.

This is an open-access article distributed under the terms and conditions of the Creative Commons Attribution license (http://creativecommons.org/licenses/by/4.0/). 